\title{
Cerebrotendinous xanthomatosis
}

\author{
Ludger Schöls, MD; Thomas Nägele MD; Rebecca Schüle, MD; \\ and Daniela Berg, MD
}

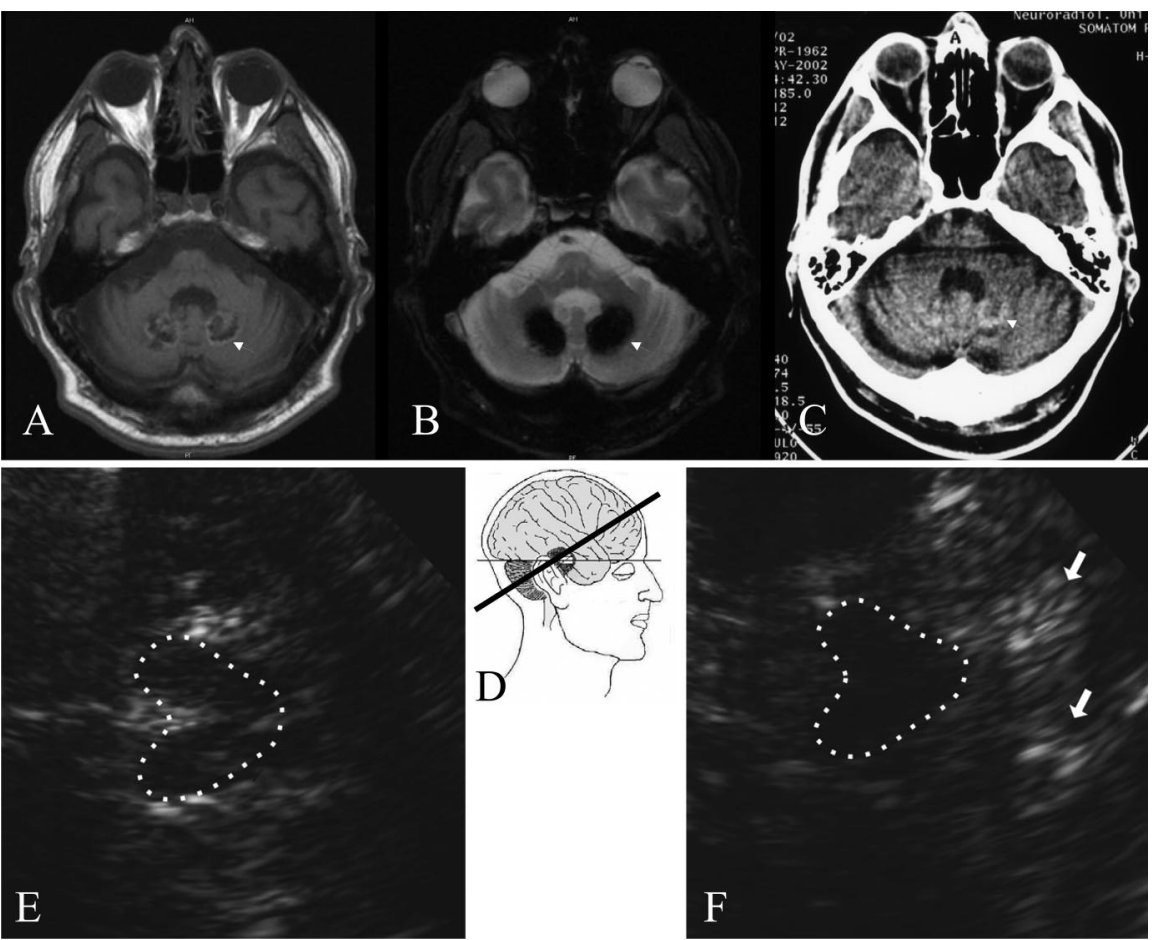

Figure. MRI revealed T1 hypointensities with hyperintense rim (A) with corresponding hyperdensity on $C T(C)$ suggestive of a mixture of calcification and hemosiderin deposits. On $\mathrm{T}_{2}^{*} \mathrm{im}$ ages $(B)$ both regions are indistinguishable hypointense due to susceptibility effects. Transcranial sonography showed in the fourth-ventricular scanning plane (D) marked hyperechogenicity of the dentate nucleus (arrows) behind the mesencephalic brainstem (dotted lines) (F) compared to a control (E).
A 43-year-old man developed progressive ataxia since 21 years of age followed by dementia, spasticity, epilepsy, and neuropathy. MRI, CT, and transcranial sonography revealed pronounced calcification and hemosiderin deposits of the dentate nucleus not affecting the basal ganglia (figure). ${ }^{1}$ CSF was normal and disorders of copper and calcium metabolism were excluded. Cholestanol and abnormal bile alcohols in plasma were increased, suggestive of 27hydroxylase (CYP27) deficiency, establishing the diagnosis of cerebrotendinous xanthomatosis. However, xanthomas were missing, as in about $30 \%$ of patients. ${ }^{2}$ Chronic diarrhea was present since infancy and juvenile cataracts were removed at age 22. Relation of these early manifestations to neurologic disease was missed and supplementation with chenodeoxycholic acid was not started before age 42. Treatment improved diarrhea and stabilized the disease but did not alleviate neurologic symptoms, as in other cases. ${ }^{2}$

\section{References}

1. Barkhof F, Verrips A, Wesseling P, et al. Cerebrotendinous xanthomatosis: The spectrum of imaging findings and the correlation with neuropathological findings. Radiology 2000; 217:869-876.

2. Moghadasian MH. Cerebrotendinous xanthomatosis: clinical course, genotypes and metabolic backgrounds. Clin Invest Med 2004;27: 42-50.

From the Department of Neurology and Hertie-Institute for Clinical Brain Research (L.S., R.S., D.B.) and Department of Neuroradiology (T.N.), EberhardKarls-University, Tübingen, Germany.

Supported by the German Ministry for Education and Research (grant 01GM0309, Leukonet) to L.S.

Disclosure: The authors report no conflicts of interest.

Address correspondence and reprint requests to Dr. Ludger Schöls, Department of Neurology and Hertie Institute for Clinical Brain Research, University of Tübingen, Hoppe-Seyler-Str. 3, D-72076 Tübingen, Germany; e-mail: Ludger.Schoels@uni-tuebingen.de

E20 Copyright () 2006 by AAN Enterprises, Inc. 


\section{Neurology}

Cerebrotendinous xanthomatosis

Ludger Schöls, Thomas Nägele, Rebecca Schüle, et al.

Neurology 2006;67;E20

DOI 10.1212/01.wnl.0000247673.08554.0f

This information is current as of December 11, 2006

\section{Updated Information \&}

Services

Supplementary Material

References

Permissions \& Licensing

Reprints including high resolution figures, can be found at: http://n.neurology.org/content/67/11/E20.full

Supplementary material can be found at: http://n.neurology.org/content/suppl/2007/05/31/67.11.E20.DC1

This article cites 2 articles, 0 of which you can access for free at: http://n.neurology.org/content/67/11/E20.full\#ref-list-1

Information about reproducing this article in parts (figures,tables) or in its entirety can be found online at:

http://www.neurology.org/about/about_the_journal\#permissions

Information about ordering reprints can be found online:

http://n.neurology.org/subscribers/advertise

Neurology ${ }^{\circledR}$ is the official journal of the American Academy of Neurology. Published continuously since 1951, it is now a weekly with 48 issues per year. Copyright . All rights reserved. Print ISSN: 0028-3878. Online ISSN: 1526-632X.

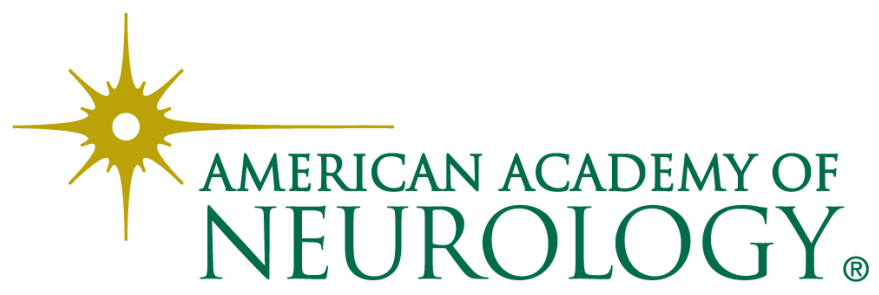

